\title{
Görüntüdeki Tuz Biber ve Gauss Gürültülerine Karşı Filtrelerin Performans Analizleri
}

\author{
Ceydanur KÜPELI ${ }^{1 *}$, Faruk BULUT ${ }^{2}$ \\ ${ }^{1}$ Haliç Üniversitesi, Bilgisayar Mühendisliği Bölümü \\ ${ }^{2}$ İstanbul Rumeli Üniversitesi, Bilgisayar Mühendisliği Bölümü
}

Geliş Tarihi: 11.07 .2020

*Sorumlu Yazar e mail: ceydanurkupeli@ogr.halic.edu.tr Kabul Tarihi: 21.09.2020

Atıf/Citation: Küpeli C., Bulut F. "Görüntüdeki Tuz Biber ve Gauss Gürültülerine Karşı Filtrelerin Performans Analizleri”, Haliç Üniversitesi Fen Bilimleri Dergisi 2020, 3/2: 211-239.

Araştırma Makalesi/ Research Article

\section{Özet}

Dijital görüntülerdeki gürültü, genellikle görüntü elde edilirken, işlenirken veya iletilirken gerçekleşir. Doğada var olan bu gürültü, görüntüye kumlu bir görünüm verir. Bu kumlu görüntüdeki noktalar, görüntüdeki verilerin kaybolduğu ya da bozulduğu anlamına gelmektedir. Bu gürültüleri temizlemek ve görüntüleri yumuşatmak için çeşitli görüntü işleme algoritmaları bulunmaktadır. Bu çalışmada, dijital fotoğraf ve videolara Tuz\&Biber ve Gauss gürültüsü eklenip Mean, Median ve Gauss filtresi kullanılarak bu gürültülerin temizlenmesi amaçlanmıştır. Temizleme işlemi yapan filtrelerin performans kıyaslaması SSIM ve PSNR ölçütlerine göre yapılmıştır. Gauss filtresinin birçok deneysel çalışmada Mean ve Median'a göre başarılı sonuçlar verdiği gözlemlenmiştir.

Anahtar Kelimeler: Yumuşatma, Filtreler, Performans Analizi

\section{Performance Analysis of Filters over Salt-Pepper and Gauss Noises in Images}

\begin{abstract}
Noise in digital images usually occurs when the image is acquired, processed or transmitted. This noise, existing in the nature, gives the image a sandy appearance. Dots in this sandy image mean that the data is lost or corrupted. There are various image processing algorithms to remove these noises and to soften the images. In this study, it was aimed to remove these noises by adding Salt-Pepper and Gaussian noises into images and videos and by using Mean, Median and Gaussian filters. The
\end{abstract}


performance comparison of the cleaning filters was made according to SSIM and PSNR criteria. It has been observed in many experimental studies that the Gauss filter gives more successful results than Mean and Median.

Keywords: Smoothing, Filters, Performance Analysis.

\section{Giriş}

Gürültü, görüntü dijital ortamdan elde edilirken veya iletilirken ortaya çıkan istenmeyen bilgidir. Gürültüler, görüntü üzerinde benekli bir görünüm oluştururlar. Görüntüdeki detayların kaybolması (verim kaybı) ve görünümün düşmesi gürültülerden kaynaklanır. Çevrenin karanlık olması ya da kamera sallanması gibi nedenlerle gürültüler oluşabilir. Gürültüleri temizlemek için görüntü işleme algoritmalarından yararlanılır. Literatürde gürültü tiplerine göre farklı yöntemler önerilmiştir.

Çalışmanın anlaşılmasına yardımcı olmak amacıyla sayısal görüntü ve video işleme hakkında temel bilgilere yer vermek gerekir. Görüntü işleme, resimsel bilgileri geliştirmek amaciyla bir görüntünün doğasını değiştirmek veya otonom makine algısı için daha uygun hale getirmek olarak adlandırılabilir. Görüntü işleme teknolojisi; görselleştirme, görüntü keskinleştirme, görüntü iyileştirme, gürültü temizleme, görüntü tanıma amacıyla kullanılabilir. Video ise birden fazla resim veya fotoğrafın peş peşe eklenmesiyle oluşur. Videoların hareketliymiş gibi görülmesinin sebebi resimlerin arka arkaya hızla oynatılmasıdır. Bir süre aralığında oynatılan kare sayısı kare hızı olarak adlandırılır. Bir videonun saniyede içerdiği resim sayısına ise frame per second denir. İnsan gözü saniyede 10 kare oynatılmasını hareketli olarak algılar. Saniyedeki kare sayısının yüksek olması görüntülerin doğal ve akıcı olarak görülmesini sağlar. Bu yüzden göz sağlığı açısından önemlidir. Video işleme yapılırken, yapılacak işlem için videodaki her bir frame çekilir. Çekilen her frame işlemlerden geçirilir ve bu frameler bir araya getirilip tekrardan videoya dönüştürülür. 
Sayısal görüntü işlemede gürültü temizleme ve yumuşatma yöntemleri üzerine son yıllarda bazı çalışmalar yapılmıştır. Bu çalışmalar sirasıyla incelenmiştir.

Ahmet ve arkadaşları tarafından, Gauss ve Tuz\&Biber gürültüsünün aynı anda bulaştığı renkli imgelerde gürültüleri azaltan bir yöntem üzerinde çalışılmıştır. Tuz\&Biber gürültüsünü temizlemek için Adaptif Ortanca filtre kullanılarak gürültülü pikseller ayrıștırılmış, Gauss gürültüsünü temizlemek için ise iyileştirilmiş iz tabanlı yaklaşım ve L2 norm uygunluk terimi kullanılmış ve görüntü yumuşatılmıştır. Gauss gürültüsünden temizlenen bu görüntünün üzerine, ayrıştırılan Tuz\&Biber gürültüleri tekrardan eklenmiştir. Tuz\&Biber gürültülü bu görüntüyü temizlemek için ise iz tabanlı yaklaşım ve L1 norm uygunluk teriminden faydalanılmış ve görüntü yumuşatılmıştır. Elde edilen sonuçlar karşılaştırılmış, yapı ve doku bilgisi kaybedilmeden renkli imgeler üzerinde çoklu gürültü gidermek için başarılı bir yöntem önerilmiştir [1].

Bir diğer çalışmada Uğur ve arkadaşları tarafından, Medyan filtre uygulamalarına alternatif bir yöntem eklenmiştir. Bu yöntem yeni piksel değerine, pencere içerisindeki piksellerden yeni bir küme oluşturarak karar verir. Gürültü yoğunluğu yüksek olsa bile, yeni piksel değerini gürültülü olmayan piksellerden elde etmeyi amaçlar. Medyan filtresi kullanılırken gürültü yoğunluğu arttıkça filtre başarımı azalır. Adaptif Medyan filtresi kullanılırken ise pencere boyutu arttığında orijinal olmayan piksel bilgisinden uzaklaşılır. Yeni yöntemle filtrelerin bu dezavantajlarının ortadan kalkması amaçlanmış ve başarılı bir sonuç elde edilmiştir [2].

Bir diğer çalışmada Gür, kümeleme algoritmalarından birisi olan $\mathrm{k}$ ortalamalar algoritması kullanarak Tuz\&Biber gürültülerini tespit edip, gürültülerin temizlenmesi için yeni bir yöntem önermiştir. Önerilen yöntem ile ortanca ve ortalama filtrelerinin performans karş1laştırmaları yapılmış ve önerilen yöntemin özellikle gürültü seviyesi arttıkça başarısının da arttığı gözlemlenmiştir. Aynı zamanda bu filtrelerin, yüksek gürültülü görüntülerdeki kenar bilgilerinin kaybolmas1 
dezavantajına karşılık gürültü içermeyen pikseller korunmuş ve bilgi kaybının önüne geçilmiştir [3].

Bir diğer çalışmada Ali ve arkadaşları, uyarlamalı Medyan ve anahtarlamalı Gauss filtresi kullanarak gürültü temizleme işlemi yapmışlardır. İlk olarak görüntüdeki Tuz\&Biber gürültüsünün temizlenmesi için görüntüye uyarlamalı medyan filtresi uygulanmış, daha sonra Tuz\&Biber gürültüsünün bulunmadığı piksellere anahtarlamalı Gauss filtresi uygulanmıştır. Anahtarlamalı Gauss filtresindeki parametreler kullanıcıdan alınmamış, otomatik olarak belirlenmiştir. Böylelikle farklı gürültü türlerinde de işlem yapılmış ve kenarların bulanıklaşmasının önüne geçilmiştir. Önerilen yöntemin standart filtrelere ve uyarlamalı medyan filtresine göre daha iyi sonuçlar verdiği gözlemlenmiştir [4].

Bir diğer çalışmada Ayşe ve arkadaşları, küçük kalsiyum birikintileri (mikrokalsifikasyonlar) içeren mamografi görüntülerini uzamsal bölgede ortanca ve ortalama filtresinden; frekans bölgesinde ise alçak geçiren ve yüksek geçiren filtrelerden geçirerek temizlemiş ve sonuçları karşılaştırmışlardır. Karşılaştırılan sonuçlara bakıldı̆̆ında hem ortanca filtrenin hem de alçak geçiren filtrenin diğer filtrelere göre daha başarılı benzerlik oranlarınasahip olduğugözlemlenmiştir. Buikifiltreyiberaber kullanmanın dijital mamografilerde mikrokalsifikasyon kümelerinin özelliklerini değiştirmeden gürültüleri azaltabileceği önerilmiştir [5].

Gürültü; hareket veya atmosferik kararsızlık nedeniyle meydana gelen bulanıklaşma veya resim çekilirken yaşanan odaklama sorunu, lenslerden kaynaklanan geometrik bozulma ve elektronik kaynaklardan gelen hatalar olarak verilebilir [1].

Gürültüyü azaltmanın temel amac1 görüntü kalitesini olabildiğince arttırmaktır. Görüntüleri bozan farklı gürültü çeşitleri mevcuttur. Bu gürültüleri gidermek için kullanılan filtreler vardır. Bu çalışmada, fotoğraf ve videolara Tuz\&Biber ve Gauss gürültüsü eklenmesi ve Mean, Medyan, Gauss filtreleri kullanılarak bu gürültülerin azaltılması ya da giderilmesi amaçlanmış ve kullanılan filtrelerin performansları kıyaslanmıştır. 


\section{Materyal ve Metot}

$\mathrm{Bu}$ bölümde bazı gürültüler hakkında çeşitli bilgiler verilmiş ve gürültü temizlemede yararlanılacak olan filtrelerin algoritmaları hakkında açıklamalar yapılmıştır. Görüntülerin değerlendirilmesi aşamasında kullanılacak olan görüntü kalite metriklerinden bahsedilmiştir.

\subsection{Görüntülerde oluşan gürültü çeşitleri}

Dijital görüntü elde edilmesi sirasında optik görüntü elektriksel sinyallere çevrilir. Doğal nedenlerden dolayı dalgalanmalar oluşur ve görüntünün piksel değerleri değişir. Böylece görüntü gürültülü bir hal alır. Gürültü birçok farklı etkenden meydana gelebilir. Görüntüleme algılayıcılarının başarımı, görüntü elde etme esnasındaki çevre koşulları ve kullanılan elemanların kalitesi gibi çeşitli faktörlerden etkilenir [6].

Görüntü sinyalinde oluşan hatalar, görüntü çıkışında, sinyaldeki bozukluk türüne bağlı olarak farklı şekilde görünür. Görüntüdeki çeşitli gürültüleri kaldırıp kusurlu görüntüyü orijinal haline getirmek gerekir.

Bu görüntü türlerinden bazıları aşağıdaki gibidir:

1. Tuz ve Biber (Dürtü) Gürültüsü

2. Gauss Gürültüsü

3. Rayleigh Gürültüsü

4. Erlang (Gama) Gürültüsü

5. Üstel Gürültü

6. Bir Biçimli Gürültü

Bu kısımda çalışmada kullanılan Tuz\&Biber ve Gauss gürültüsünden bahsedilmiştir. 


\subsubsection{Gauss gürültüsü}

Gauss gürültüsü, olasılık yoğunluk fonksiyonu tarafından tanımlanan rastgele değişkenlerin istatistiksel davranışıdır. Bu gürültü genellikle görüntü elde edilirken sinyallerde oluşan bozukluklara bağlı olarak ortaya çıkar ve piksellerin gerçek değerlerinin değişmesiyle meydana gelir. Histogram, bir görüntüdeki renk değerlerinin s1klığını gösteren bir grafiktir. Belirlenen sigma değerine göre Gauss dağılımı üretilir. Histogram, gürültünün Gauss dağılımını gösterir. Piksellerdeki değişim oranlarının belirli bir histogram değeri içinde olması durumunda gürültü hakkında yorum yapılabilir. Gauss dağ1lımı, ortalama değerde en yüksektir. Gauss gürültüsünde ise görüntü üzerindeki değişim, ortalama gri ton üzerinde 0'dır. Yani histogramdaki en yüksek bu değerin, ortalama gri tondan uzaklığı da 0'dır. Bu değerlerin ortalama değere olan uzaklıkları piksellerin ne kadar değişeceğini verir [7].

Gauss rastgele değişkeninin olasılık yoğunluk fonksiyonu eşitlik (1)' de verilmiştir.

$$
\text { Histogram } \text { Gauss }=\frac{1}{\sigma \sqrt{2 \pi}} e^{-\frac{(g-m)^{2}}{2 \sigma^{2}}}
$$

Burada $g$, gri ton seviyesini; $m$, Gauss gürültüsünün ortalama değerini; $e$, doğal logaritma tabanını; son olarak da $\sigma$, standart sapmayı temsil eder [8].

Şekil 1'de orijinal görüntü ve bu görüntüye farklı oranlarda Gauss gürültüsünün eklenmesi ile oluşan yeni görüntüler verilmektedir. Bu çalışmada, Görüntü İşleme alanında dünyaca ünlü kıyaslamalı bir veri setinden baboon.png fotoğrafi tercih edilmiştir [9]. Bunun sebebi Baboon görüntüsünün kendine özgü renk ve doku karışımından oluşmasıdır. Gürültü oranına ve filtrelere göre görüntüdeki detay kaybını veya orijinalliği yorumlamayı kolaylaştırmıştır. Görüldüğü üzere gürültü oranı arttıkça fotoğraftaki detaylar da kaybolmaktadır. 


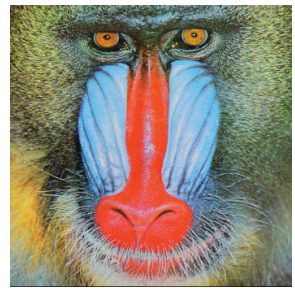

(a)

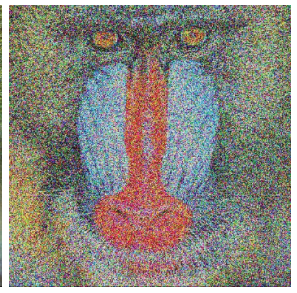

(b)

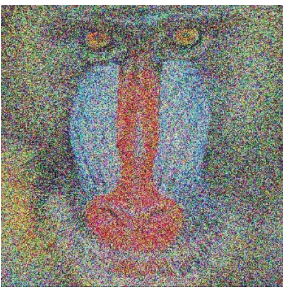

(c)

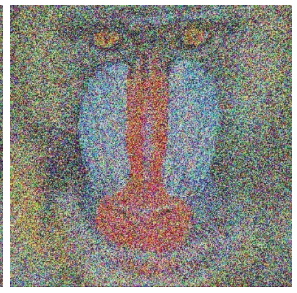

(d)

Şekil 1. (a) Orijinal Görüntü, (b) \%40 Gauss Gürültülü Görüntü, (c) \%60 Gauss Gürültülü Görüntü, (d) \%80 Gauss Gürültülü Görüntü [9]

\subsubsection{Tuz\&Biber gürültüsü}

Tuz ve biber gürültüsü dürtü tipi bir gürültüdür. Beyaz arka plan üzerinde siyah pikseller ve siyah arka plan üzerinde beyaz pikseller içerir. Siyah noktalar 0, beyaz noktalar 255 değerini alır. Bu gürültünün önemli bir özelliği, gürültülü pikselin ağırlığının veya değerinin komşu piksellerin rengi ile hiçbir bağlantısı veya ilişkisi olmamasıdır. Bu gürültü türü genellikle az sayıda görüntü pikselini etkiler. Bu piksel türü görüntülendiğinde, siyah beyaz noktalara benzer. Genelde data iletimindeki hatalar sonucu oluşur. Bu tür gürültü kaynakları, hatalı bellek konumları, kameradaki toz veya arıalı elemanlardir [6].

Şekil 2'de orijinal görüntü ve bu görüntüye farklı oranlarda Tuz\&Biber gürültüsünün eklenmesi ile oluşan yeni görüntüler yer almaktadır. Tuz\&Biber gürültüsünün tahrip yeteneği aynı orandaki Gauss'a göre daha fazladır. Kıyaslama yapılacak olursa Şekil 1 (d)'de bulunan görüntü, Şekil 2 (d)'de bulunan görüntüye göre gözle görülebilecek detaylara sahiptir. 


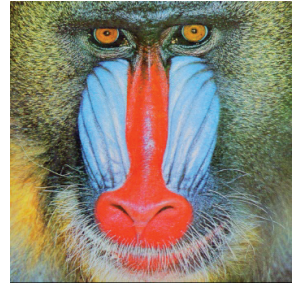

(a)

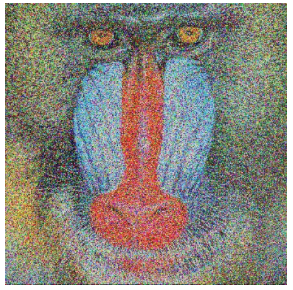

(b)

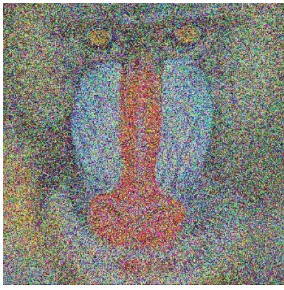

(c)

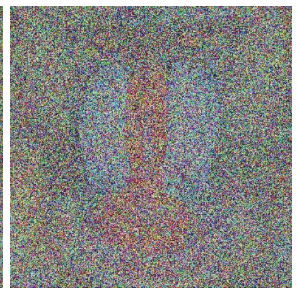

(d)

Şekil 2. (a) Orijinal Görüntü, (b) \%40 Tuz\&Biber Gürültülü Görüntü, (c) \%60 Tuz\&Biber Gürültülü Görüntü, (d) \%80 Tuz\&Biber Gürültülü Görüntü [9]

\subsection{Gürültünün etkisini azaltan görüntü işleme algoritmaları}

Filtreler görüntülere, gürültüleri temizlemek, görüntüyü düzleştirmek ve kenarları iyileştirmek için uygulanır. Yüksek frekans bileşenli gürültülerde alçak geçirgen filtreler, düşük frekans bileşenli gürültülerde yüksek geçirgen filtreler uygulanırsa daha iyi sonuç elde edilir [7].

Filtre işlemleri uzaysal ortamda ve frekans ortamında gerçekleşebilir. Bu çalışmada gürültüler, uzaysal ortamda lineer ve lineer olmayan filtreler kullanılarak temizlenmiştir. Gauss ve Mean filtresi lineer filtre iken Medyan filtresi lineer olmayan bir filtredir. Burada lineer olmanın anlamı, her adımda merkeze denk gelen piksellerin hepsine aynı işlemin uygulanmasıdır. Lineer filtreler keskin kenarları bulanıklaştırmada, çizgileri ve diğer ince görüntü ayrıntılarını yok etmede ve sinyale bağlı parazit varlığında kötü performans gösterir [7].

\subsubsection{Mean (Ortalama) filtresi}

Mean filtresine ortalama filtre de denmektedir. Görüntüdeki gürültüleri azaltmada kullanılan süzgeçlerden (filtrelerden) en basitidir. Görüntü işleme algoritmaları bir görüntüyü bilgisayar yardımıyla işleyebilmek amacıyla ilk adımda söz konusu görüntüyü iki veya daha 
fazla boyuta sahip bir matrise dönüştürür. Bu matrisin her bir elemanının değeri ilgili görüntünün her bir pikselinin sayısal değerine eşittir [7].

Ortalama filtre, belirli bir pencere aralığındaki sayıların ortalamasını bulmayı ve bu sayede söz konusu sayılar arasındaki aşırı farklılıkları ortadan kaldırmayı hedeflemektedir. Başka bir deyişle, bu filtre sayesinde komşularından belirgin bir şekilde ayrışan piksellerin tespit edilmesi ve yumuşatılması amaçlanmaktadır.

Ortalama filtre, bir görüntüdeki her bir piksel için pencere boyutundaki komşu piksellerin ortalama değerini elde eder ve ilgili piksele bu ortalama değerini atar. $\mathrm{Bu}$ işlem her bir piksel için sırasıyla uygulanır. $3 \times 3$ 'lük komşuluk belirlenirken filtre uygulanan piksel bu matrisin ortasına getirilerek komşuları belirlenir. $\mathrm{Bu}$ değerler toplanır ve ortalama hesaplanır. Genellikle 3×3'lük pencere kullanılır ancak görüntünün daha çok düzleştirilmesi beklendiğinde pencerenin boyutu arttırılır. $\mathrm{Bu}$ filtrenin dezavantajlarından birisi pencere boyutu artt1rıldığında görüntünün bulanıklaşmasıdır. Mean filtresi için 3x3'lük maske Şekil 3’te verilmiştir [10].

\begin{tabular}{|c|c|c|}
\hline 1 & 1 & 1 \\
\hline$\frac{1}{9} \times$ & 1 & 1 \\
\hline 1 & 1 & 1 \\
\hline
\end{tabular}

Şekil 3. 3×3' lük Mean Maskesi

Şekil 4'te orijinal görüntü, bu görüntünün $\% 40$ oranında Tuz\&Biber gürültülü hâli ve Mean filtresinden geçirilmiş hâli verilmiştir. $\mathrm{Bu}$ filtreleme sonucunda görüntüye ait detayların çoğunlukla kaybolduğu görülmüş̧ür. 


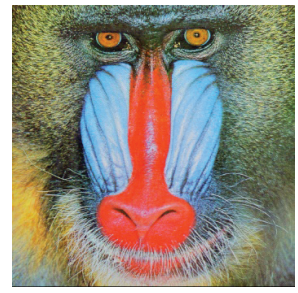

(a)

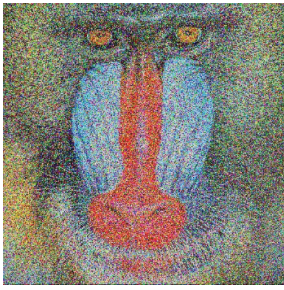

(b)

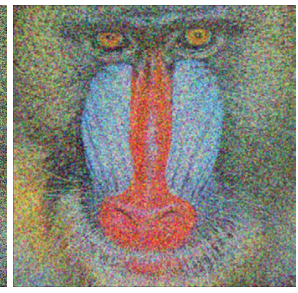

(c)

Şekil 4. (a) Orijinal Görüntü (b) \%40 Tuz\&Biber Gürültülü Görüntü (c) Mean Filtresinden Geçirilmiş Görüntü [9]

Şekil 5'te orijinal görüntü, bu görüntünün $\% 40$ oranında Gauss gürültülü hâli ve Mean filtresinden geçirilmiş hâli verilmiştir [9].

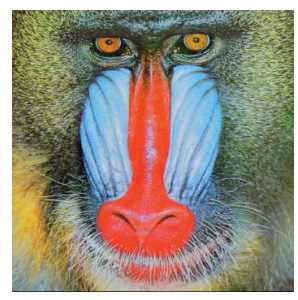

(a)

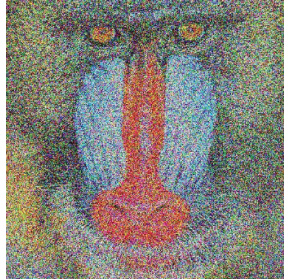

(b)

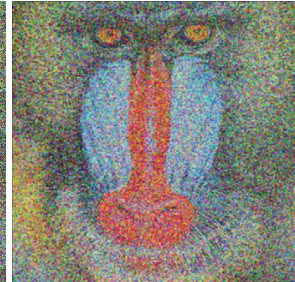

(c)

Şekil 5. (a) Orijinal Görüntü (b) \%40 Gauss Gürültülü Görüntü (c) Mean Filtresinden Geçirilmiş Görüntü

Şekil 4 ve Şekil 5'de bulunan (c) görüntüleri incelendiğinde (b)'ye göre kabul edilebilir düzeyde daha iyi detaylara sahiptir. Burada filtrelemenin ne kadar önemli olduğu gözlemlenmektedir.

\subsubsection{Medyan (Ortanca) filtresi}

Medyan filtresine orta değer filtresi de denmektedir. Medyan filtresi de ortalama filtresi gibi gürültü yumuşatma amacıyla kullanılır. Ortalama filtresine kıyasla daha iyi performans gösterir. Az bulanıklaştırma ile mükemmel gürültü azaltma amacı güder [7]. 
Medyan filtre, belirli bir pencere aralığındaki sayıları belirli bir düzene göre sıralayıp ortancasını bulur ve pencerenin ortasına koyar. Gürültü yüzdesinin yüksek olduğu durumlarda daha iyi iş çıkarmıştır.

Şekil 6'da orijinal görüntü, bu görüntünün \%40 oranında Tuz\&Biber gürültülü hâli ve Medyan filtresinden geçirilmiş hâli verilmiştir.

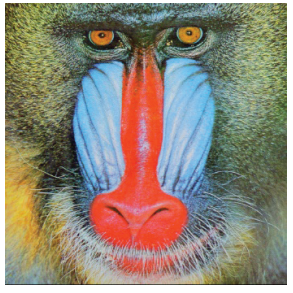

(a)

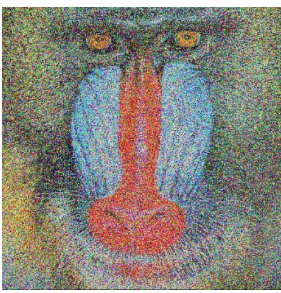

(b)

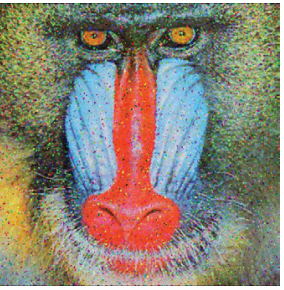

(c)

Şekil 6. (a) Orijinal Görüntü (b) \%40 Tuz\&Biber Gürültülü Görüntü (c) Medyan Filtresinden Geçirilmiş Görüntü [9]

Şekil 7'de orijinal görüntü, bu görüntünün \%40 oranında Gauss gürültülü hâli ve Medyan filtresinden geçirilmiş hâli verilmiştir.

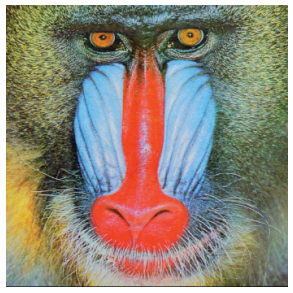

(a)

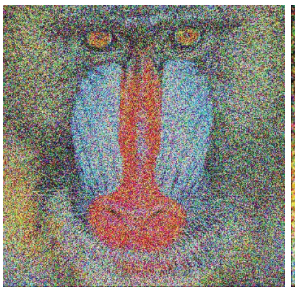

(b)

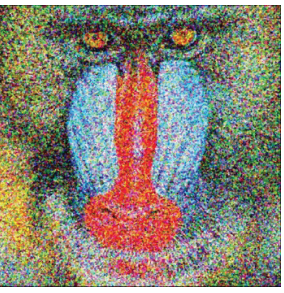

(c)

Şekil 7. (a) Orijinal Görüntü (b) \%40 Gauss Gürültülü Görüntü (c) Medyan Filtresinden Geçirilmiş Görüntü [9]

Şekil 6 ve Şekil 7'de bulunan (c) görüntüleri incelendiğinde (b)'ye göre daha belirgin ve gözlemlenebilir detaylara sahiptir. Özellikle Şekil 6 (c)'de yüksek bir temizleme işlemi gerçekleştirilmiştir. Burada filtrelemenin ne denli gerekli bir işlem olduğu kanıtlanmaktadır. 


\subsubsection{Gauss filtresi}

Gauss filtresi, gürültünün daha aza indirgenmesi için kullanılan lineer filtrelerden biridir. Ancak tuz ve biber gürültülerini indirgemekte çok etkili değildir. Gauss filtresi, Gauss fonksiyonundan elde edilir.

2 boyutlu Gauss fonksiyonunun formülü eşitlik (2)' deki gibidir [4].

$$
g(x, y, \sigma)=\frac{1}{2 \pi \sigma^{2}} e^{-\frac{x^{2}+y^{2}}{2 \sigma^{2}}}
$$

Burada $s$ standart sapmayı, $x$ yatay eksendeki merkezden uzaklığı, $y$ dikey eksendeki merkezden uzaklığı ve $e$ de doğal logaritma tabanını ifade eder.

$\mathrm{s}=1$ için 2 boyutlu gauss dağılımı Şekil 8 'deki gibidir. Standart sapma veri değerlerinin ortalamaya olan uzaklığı olarak tanımlanabi$\operatorname{lir}[7]$.

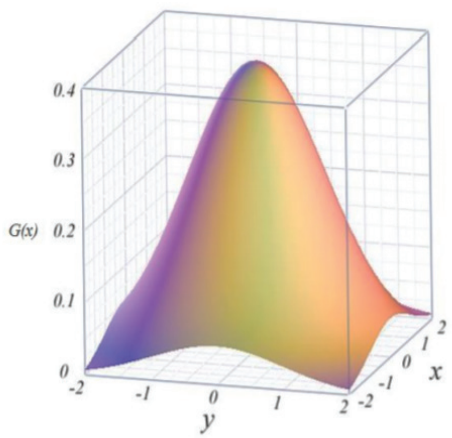

Şekil 8. $\mathrm{s}=1$ için 2 Boyutlu Gauss Dağılımı

Gauss filtresi her hücredeki renk değerinin penceredeki hücrelerle çarpılmasıyla oluşur. Gauss maskesinin değerleri pencere boyutu ve standart sapmaya göre belirlenir. Standart sapma kullanıcı tarafından belirlenebilir. Standart sapma değeri büyük olduğunda daha geniş bir tepe noktası oluşur. Bu da görüntünün daha bulanık olmasına sebep olur. $3 \times 3$ ' lük maske kullanırken $x$ ve y'nin değer aralığ $1-1,0,1$ 
seçilir. Standart sapma değerine göre maske değerleri belirlenir. Gauss maskesinde ortadaki hücrenin etkisinin yüksek olması beklenirken kenardaki hücrelerin etkisinin az olması beklenir. Farklı boyutlardaki Gauss maskeleri Şekil 9'da verilmiştir [4][7].

Şekil 9'da sırasıyla 3×3'lük, 5×5'lik, 7×7'lik Gauss maskesi verilmiştir.

\begin{tabular}{|c|c|c|c|}
\hline \multirow{3}{*}{$1 / 16$} & 1 & 2 & 1 \\
\hline & 2 & 4 & 2 \\
\hline & 1 & 2 & 1 \\
\hline
\end{tabular}

\begin{tabular}{|c|c|c|c|c|}
\hline 1 & 4 & 7 & 4 & 1 \\
\hline 4 & 16 & 26 & 16 & 4 \\
\hline 7 & 26 & 41 & 26 & 7 \\
\hline 4 & 16 & 26 & 16 & 4 \\
\hline 1 & 4 & 7 & 4 & 1 \\
\hline
\end{tabular}

\begin{tabular}{|c|c|c|c|c|c|c|}
\hline 0 & 0 & 1 & 2 & 1 & 0 & 0 \\
\hline 0 & 3 & 13 & 22 & 13 & 3 & 0 \\
\hline 1 & 13 & 59 & 97 & 59 & 13 & 1 \\
\hline 2 & 22 & 97 & 159 & 97 & 22 & 2 \\
\hline 1 & 13 & 59 & 97 & 59 & 13 & 1 \\
\hline 0 & 3 & 13 & 22 & 13 & 3 & 0 \\
\hline 0 & 0 & 1 & 2 & 1 & 0 & 0 \\
\hline
\end{tabular}

Şekil 9. 3×3'lük, 5×5'lik, 7×7'lik Gauss Maskesi [11]

Şekil 10'da sirasıyla orijinal görüntü, \%40 oranında Tuz\&Biber gürültülü görüntü ve Gauss filtresinden geçirilmiş görüntü verilmiştir.

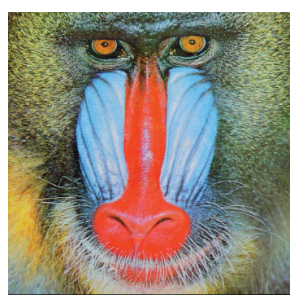

(a)

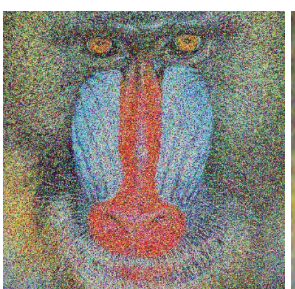

(b)

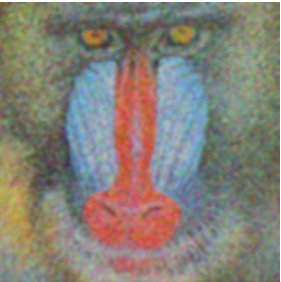

(c)

Şekil 10. (a) Orijinal Görüntü (b) \%40 Tuz\&Biber Gürültülü Görüntü (c) Gauss Filtresinden Geçirilmiş Görüntü [9]

Şekil 11'de sırasıyla orijinal görüntü, $\% 40$ oranında Gauss gürültülü görüntü ve Gauss filltresinden geçirilmiş görüntü verilmiştir. 


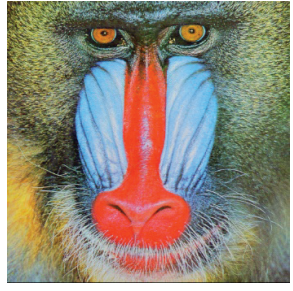

(a)

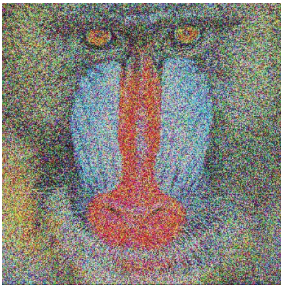

(b)

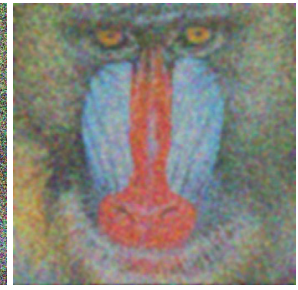

(c)

Şekil 11. (a) Orijinal Görüntü (b) \%40 Gauss Gürültülü Görüntü (c) Gauss Filtresinden Geçirilmiş Görüntü [9]

Şekil 10 ve 11 'in (c) kısmında gürültünün temizlenmesi neticesinde oluşan görüntüler yer almaktadır. Burada bariz bir şekilde bulanıklaşma söz konusudur. Bu da filtrelemenin başarısız olduğunu göstermektedir.

\subsection{Görüntü kalitesini ölçen metrikler}

Gürültü eklenen görüntüler, filtrelerden geçirildikten sonra filtrelerin performans kıyaslaması yapılır. Performans analizi yapılırken orijinal görüntü ile filtrelenmiş görüntünün görüntü kalitesinin karşılaşt1rılması gerekir. Bu karşılaştırma insan gözüyle değil kalite metrikleriyle yapılır.

Karşılaştırma yaparken; bozulmamış görüntünün mevcut olduğu durumlarda tam referans kalite metrikleri kullanılır, bozulmamış bir görüntü mevcut değilse referanssız kalite metrikleri kullanılır [12].

Tam referans kalite metrikleri, bozulmamış görüntüyü referans alıp hedef görüntüyle karşılaştırarak kalite değerlendirmesi yapar.

Bu kalite metriklerinden bazıları aşağıdaki gibidir [14]:

1. Ortalama Karesel Hata (Mean-Squared Error - MSE)

2. Tepe Sinyali Gürültü Oranı (Peak Signal to Noise Ratio - PSNR)

3. Yapısal Benzerlik Endeksi (Structural Similarity Index - SSIM)

$\mathrm{Bu}$ çalışmada, görüntü kalitesi karşılaştırılırken PSNR ve SSIM metriklerinden yararlanılmıştır [12]. 


$$
M S E=\frac{1}{n} \sum_{j=1}^{n} e_{j}^{2}
$$

MSE ölçeği, tahmin edilen piksel değerinin gerçek piksel değerlerine yakınlığını ölçer. MSE eşitlik (3)’te gösterildiği gibi ifade edilir. Bu eşitlikte $n$ tahmin edilecek piksel sayısını, $e_{j}$ tahmin edilen değerin gerçek değerden farkını ifade eder. MSE değeri ne kadar büyük olursa tahmin edilen değer gerçek değere o kadar yakındır [12].

$$
P S N R=10 \log _{10}\left(\frac{M A x_{I}^{2}}{M S E}\right)
$$

PSNR ölçeği, iki görüntü arasındaki tepe sinyalinin gürültünün gücüne oranını hesaplar. Tepe sinyali gerçek değeri, gürültü ise hatayı ifade eder. PSNR ne kadar yüksek olursa görüntünün kalitesi o kadar iyi olur. PSNR eşitlik (4)’te gösterildiği gibi ifade edilir. Bu eşitlikte $M A X_{I}$ orijinal görüntüdeki maksimum tepe sinyal değerini, $M S E$ ise MSE ölçek değerini ifade eder [10]

$$
\operatorname{SSIM}(x, y)=\frac{\left(2 \mu_{x} \mu_{y}+c_{1}\right)\left(2 \sigma_{x y}+c_{2}\right)}{\left(\mu_{x}^{2}+\mu_{y}^{2}+c_{1}\right)\left(\sigma_{x}^{2}+\sigma_{y}^{2}+c_{2}\right)}
$$

SSIM ölçeği, orijinal görüntü ve referans görüntü arasındaki alg1sal farkı ölçer. PSNR' den farklı olarak görüntüdeki görünür yapılara dayanır. Bu ölçek görüntünün çeşitli pencerelerinde hesaplanır. Eşitlik (5)'teki $x$ ve $y$ pencerelerdir. Burada $\mu$ ortalamay1, $\sigma^{2}$ varyansı, $\sigma$ kovaryans1, $c_{1}$ ve $c_{2}$ ise sabit değişkenleri ifade eder. SSIM ölçeği, -1 ve 1 arasında değer alır ve 1'e yaklaştıkça görüntü kalitesi artar.

Referanssız kalite metrikleri, giriş görüntüsünün istatistiksel özelliklerini kullanarak kalite değerlendirmesi yapar. Bu kalite metriklerinden bazıları aşağıdaki gibidir:

- Kör/Referanssız Görüntü Mekansal Kalite Değerlendiricisi (Blind/Referenceless Image Spatial Quality Evaluator RISQUE)

- Doğal Görüntü Kalite Değerlendiricisi (Natural Image Quality Evaluator - NIQE) 
RISQUE ölçeği, sadece aynı türden bozulmaların görüntü kalitesini değerlendirir. 0 ile 100 arasında bir değer alır. RISQUE değeri 0'a ne kadar yakınsa görüntü o kadar kalitelidir [12].

NIQE ölçeği, rastgele bozulmalarla görüntünün kalitesini ölçer. NIQE değeri ne kadar düşükse görüntü o kadar kalitelidir [12].

\section{Proje Tasarım ve Deneysel Uygulama}

\subsection{Proje tasarım}

$\mathrm{Bu}$ bölümde çalışma senaryosu ve tasarımı hakkında bilgi verilmiştir. Kullanılan yöntemlere ve aşamalara ait akış diyagramı gösterilmiştir.

Fotoğraf ve videolarda oluşan gürültülerin görüntü işleme algoritmaları ile giderilmesi ve algoritmaların performans kıyaslamasının yapılmasıdır. Proje MATLAB GUI kullanılarak MATLAB R2019b ortamında yapılmıştır. MATLAB R2019b versiyonunun lisansı alınmıştir.

MATLAB, ilk başta matrislerle yapılan işlemleri kolaylaştıran bir kütüphane olarak tasarlanmıştır. Günümüzde de matris işlemleri yapilırken en çok tercih edilen programdır. Proje MATLAB GUI ortamında görüntü işleme algoritmaları kullanılarak yapılmıştır. GUI; push button, axes, panel, edit text gibi bileşenlerden oluşarak kullanıcı ile sistem arasında bağlantı kurmaya yarar [13].

Tasarlanan program açıldığında, gelen ana sayfada görüntü filtreleme veya video filtreleme için seçim işlemi yapılır. Görüntü filtreleme yaparken, işlem yapılmak istenen görüntü seçilir ve ekranda gösterilir. Seçilen görüntü için eklenmek istenen gürültü miktarı girilir. Tuz\&Biber veya Gauss gürültülerinden biri seçilerek görüntüye gürültü eklenir ve ekranda gösterilir. Görüntüyü filtrelemek için maske boyutu girilir. Mean, Medyan veya Gauss filtrelerinden biri seçilerek görüntü filtrelenir ve ekranda gösterilir. Filtrelerin performans analizi PSNR ve SSIM ölçütleriyle yapılır. Ana sayfaya geri dönüş yapılarak yeni işlem seçilebilir. Video filtreleme yaparken, işlem yapılmak 
istenen video seçilir ve ekranda gösterilir. Seçilen video için eklenmek istenen gürültü miktarı girilir. Tuz\&Biber veya Gauss gürültülerinden biri seçilerek videoya gürültü eklenir. Gürültülü video kaydedilir ve ekranda gösterilir. Videoyu filtrelemek için maske boyutu girilir. Mean, Medyan veya Gauss filtrelerinden biri seçilerek video filtrelenir. Filtrelenen video kaydedilir ve ekranda gösterilir. Filtrelerin performans analizi PSNR ve SSIM ölçütleriyle yapılır. Ana sayfaya geri dönüş yapılarak yeni işlem seçilebilir. Şekil 13'te ve Şekil 14'te bu adımlar ayrıntılı olarak gösterilmiştir.

Geliştirilen algoritma şekillerle ifade edilmiştir. Projeye ait akış diyagramı Şekil 12'de verilmiştir.

Kullanıc MATLAB ortamına resim ve video yükleyerek test yapar. Bu diyagrama göre program çalıştırıldığında ana sayfa ekrana gelir ve seçim yapılır. Görüntü ve video seçimine göre Şekil 12'de verilen aşamalar gerçekleştirilir. Ana sayfaya geri dönerek programdan çıkış yapılır. 


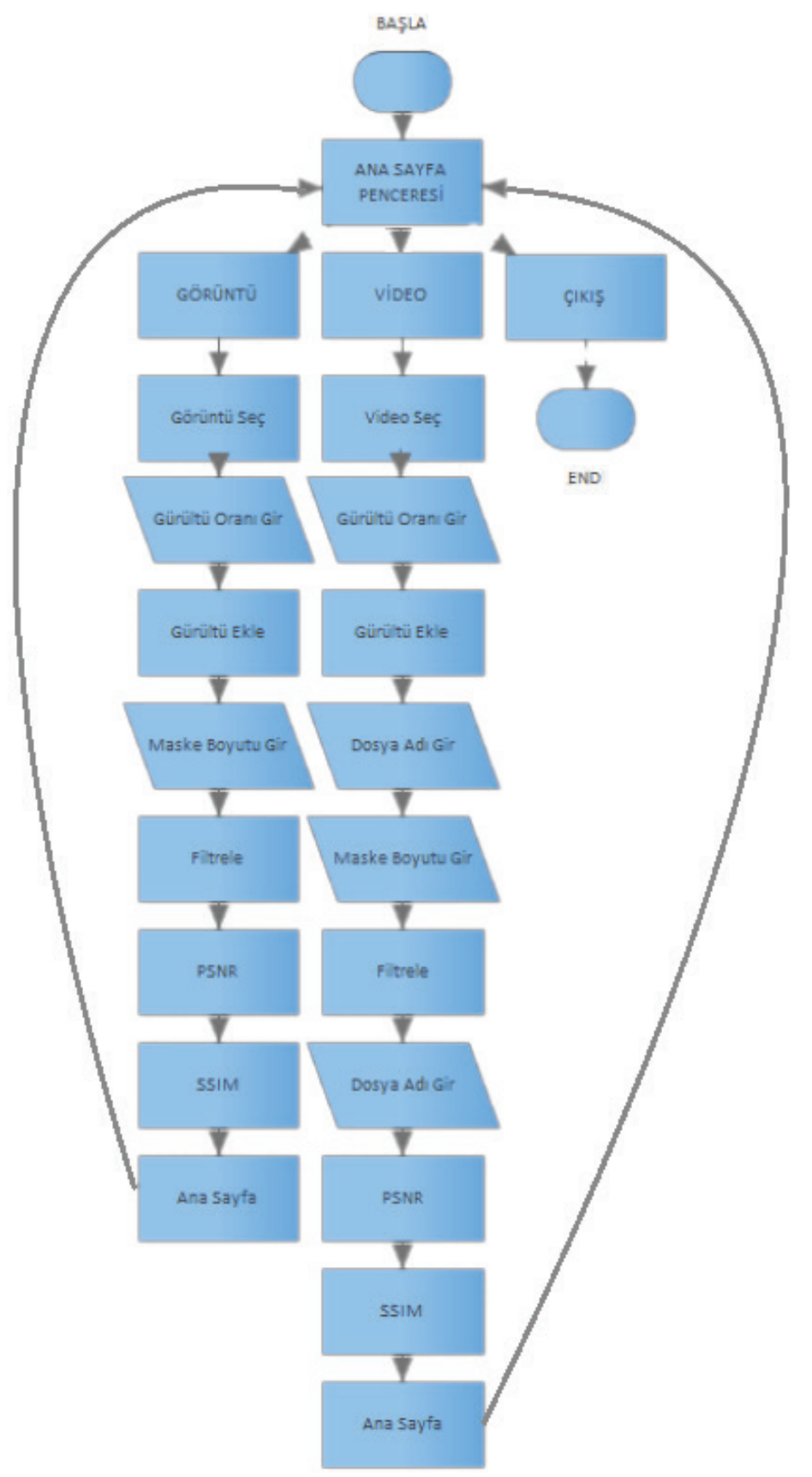

Şekil 12. Akış Diyagramı 


\subsection{Uygulama arayüzleri}

Bu bölümde uygulamanın arayüzleri gösterilmiştir. Kullanıcı projenin bulunduğu dosyaya görüntü ve video ekledikten sonra uygulama çalıştırılır. Uygulama çalıştırıldığında seçimlerin yapılacağı ana sayfa ekrana gelir ve buradan seçim yapılır.

“GÖRÜNTÜ SEÇİNIZ” butonuna tıklandığında görüntünün seçileceği dosya aç1lır ve görüntü seçilir. Seçilen görüntü ekranda gösterilir. Orijinal görüntü ekranda gösterildikten sonra gürültü oranı girilir ve gürültü tipi seçilir. Görüntünün gürültü hali ekranda gösterilir. Şekil 13 ’te gürültülü görüntünün oluşma aşaması gösterilmiştir.

Gürültülü görüntü ekranda gösterildikten sonra maske boyutu girilir ve filtre tipi seçilir. Filtrelenmiş görüntü ekranda gösterilir. Maske boyutu tek sayı girilmelidir. Filtrelenmiş görüntü ekranda gösterildikten sonra metrikler bölümündeki "PSNR" ve "SSIM" butonları arac1lığıyla görüntü kalitesi değerlendirilir. Görüntü kalitesi değerlendirme aşaması Şekil 13’te gösterilmiştir.

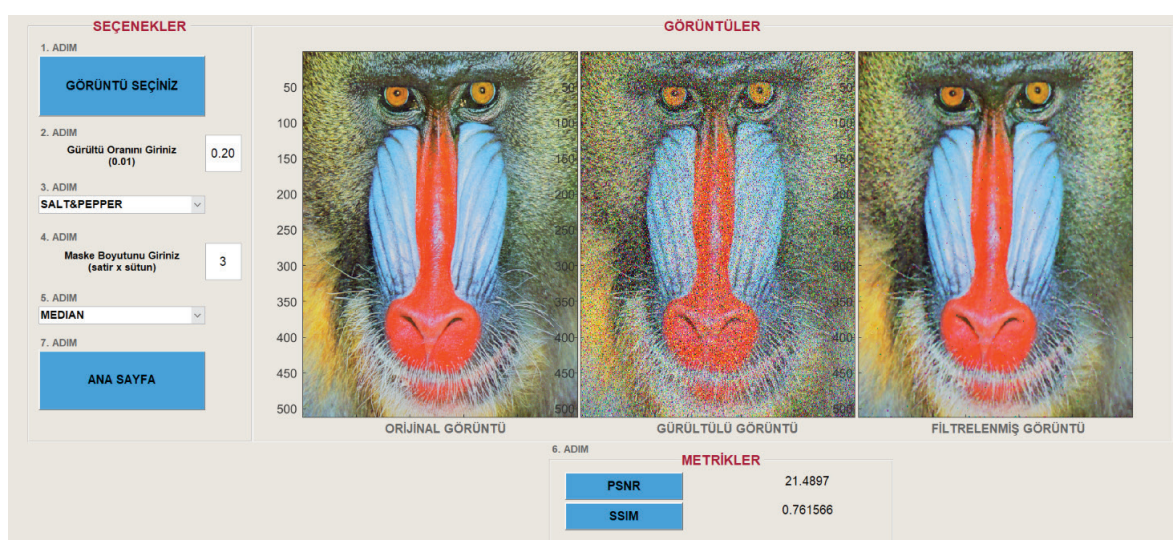

Şekil 13. Filtrelenmiş Görüntünün Ekranda Gösterilmesi ve Görüntü Kalitesi Değerlendirilmesi

"VİDEO SEÇİNIZ" butonuna tıklandığında videonun seçileceği dosya açılır ve video seçilir. Seçilen video ekranda gösterilir. Orijinal 
video ekranda gösterildikten sonra gürültü oranı girilir ve gürültü tipi seçilir. Gürültü tipi seçildikten sonra, gürültülü videonun kaydedilmesi için dosya adı girilir. Böylece gürültülü video hem ekranda gösterilmiş hem de dosyaya kaydedilmiş olur. Gürültülü video ekranda gösterildikten sonra maske boyutu girilir ve filtre tipi seçilir. Filtre tipi seçildikten sonra, filtrelenmiş videonun kaydedilmesi için dosya adı girilir ve video kaydedilir. Böylece filtrelenmiş video hem ekranda gösterilmiş hem de dosyaya kaydedilmiş olur.

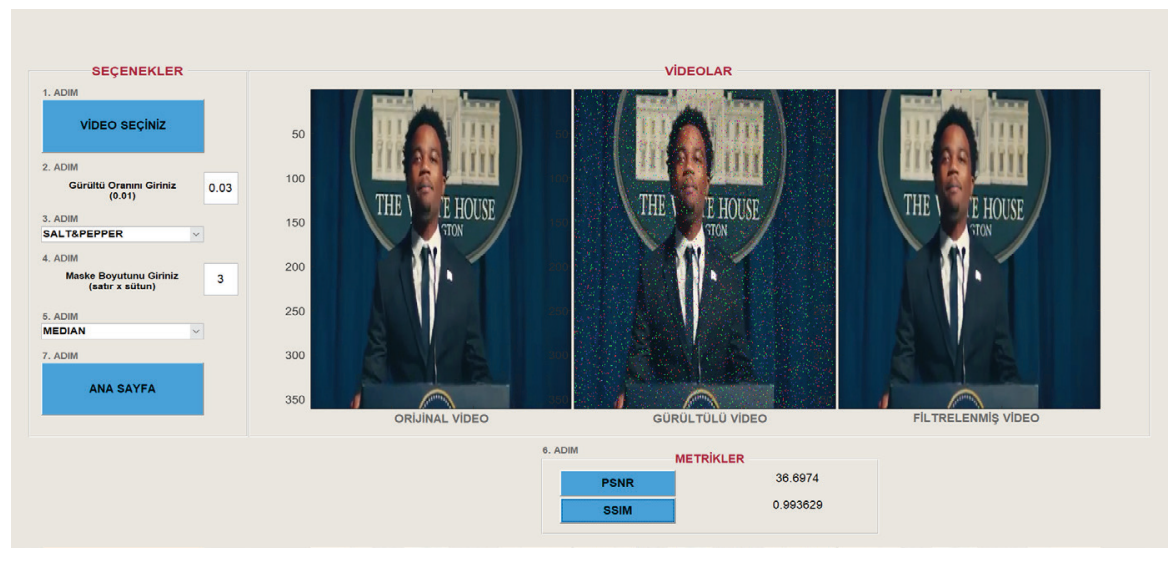

Şekil 14. Filtrelenmiş Videonun Ekranda Gösterilmesi

Filtrelenmiş video ekranda gösterildikten sonra metrikler bölümündeki "PSNR" ve "SSIM" butonları aracılığıyla görüntü kalitesi değerlendirilir. Videodaki her bir frame tek tek işlemden geçtiği için bu butonların cevap vermesi uzun sürmektedir. Şekil 14'te gürültülü videonun filtrelenme aşaması ve görüntü kalitesi değerlendirme aşamas1 gösterilmiştir.

Videolar ekranda gösterilirken yavaş çalışır. Videonun normal süresinden daha uzun bir sürede gösterilir. Videoları gerçek hızında oynatmak için videolar kaydedilmiştir. 


\section{Bulgular ve Tartışma}

$\mathrm{Bu}$ bölümde görüntü kalitesi değerlendirilerek filtrelerin performans analizi yapılmıştır. Filtrelerin performans analizini yapmak için, görüntü işleme uygulamalarında en çok kullanılan 4 adet kıyaslamalı test görüntüsü kullanılmıştır [9]. Şekil 15 'te $512 \times 512$ boyutundaki görüntüler sırasıyla airplane.png, baboon.png, lena.png, peppers.png' dir.
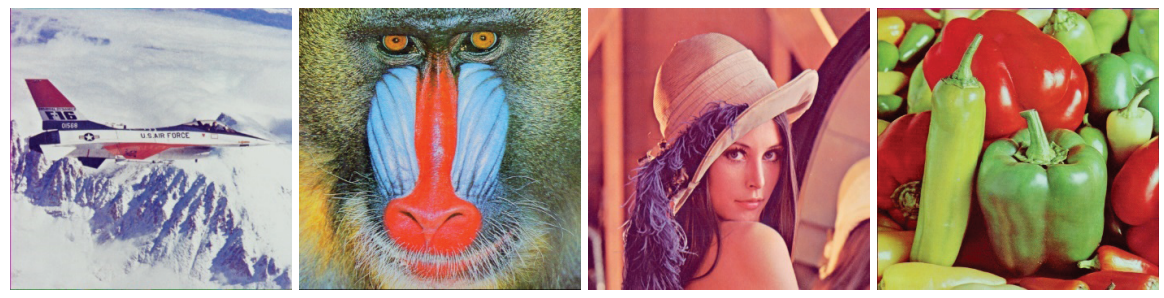

Şekil 15. Test Görüntüleri

Görüntü kalitesi değerlendirilirken PSNR ve SSIM yöntemlerinden yararlanılmıştır. Görüntülere farklı oranlarda gürültü uygulanmış, $3 \times 3$ ve $5 \times 5$ maske boyutu kullanılıp filtrelerin karşılaştırılması yapılmıştır. Tablo 1'de görüntülerin PSNR sonuçları gösterilmiştir. 
Tablo 1. Farklı Gürültü Oranları için PSNR Değerleri

\begin{tabular}{|c|c|c|c|c|c|c|c|}
\hline Görüntü & $\begin{array}{c}\text { Gürültüi } \\
\text { Tipi }\end{array}$ & $\begin{array}{l}\text { Maske } \\
\text { Boyutu }\end{array}$ & Filtre Tipi & $\% 1$ & $\% 20$ & $\% 50$ & $\% 80$ \\
\hline \multirow{7}{*}{ 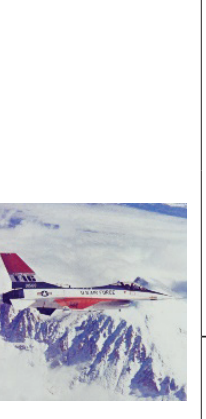 } & \multirow{6}{*}{ Tuz\&Biber } & \multirow{3}{*}{$3 \times 3$} & MEAN & 28.5 & 19.5 & 14.4 & 11.3 \\
\hline & & & MEDYAN & 34.1 & 27.4 & 14.5 & 7.5 \\
\hline & & & GAUSS & 24.4 & 21.1 & 16.2 & 12.8 \\
\hline & & \multirow{3}{*}{$5 \times 5$} & MEAN & 25.9 & 20.7 & 15.6 & 12.3 \\
\hline & & & MEDYAN & 29.7 & 26.9 & 21.1 & 9.7 \\
\hline & & & GAUSS & 22.2 & 20.1 & 16 & 12.8 \\
\hline & \multirow{6}{*}{ Gauss } & \multirow{3}{*}{$3 \times 3$} & MEAN & 26.7 & 17.1 & 14.4 & 13.4 \\
\hline \multirow{5}{*}{ PLANE } & & & MEDYAN & 26.5 & 15.4 & 12.2 & 10.8 \\
\hline & & & GAUSS & 24.4 & 19.3 & 16.3 & 15.1 \\
\hline & & \multirow{3}{*}{$5 \times 5$} & MEAN & 25.5 & 18.6 & 15.6 & 14.5 \\
\hline & & & MEDYAN & 27.1 & 18.3 & 15.1 & 13.6 \\
\hline & & & GAUSS & 22.2 & 18.7 & 16.1 & 15 \\
\hline \multirow{12}{*}{ BABOON } & \multirow{6}{*}{ Tuz\&Biber } & \multirow{3}{*}{$3 \times 3$} & MEAN & 22.4 & 18.6 & 14.9 & 12.5 \\
\hline & & & MEDYAN & 23.1 & 21.5 & 14.1 & 7.8 \\
\hline & & & GAUSS & 19.9 & 18.9 & 16.6 & 14.2 \\
\hline & & \multirow{3}{*}{$5 \times 5$} & MEAN & 20.5 & 18.9 & 16.1 & 13.7 \\
\hline & & & MEDYAN & 20.8 & 20.3 & 18.4 & 9.8 \\
\hline & & & GAUSS & 19.1 & 18.4 & 16.4 & 14.3 \\
\hline & \multirow{6}{*}{ Gauss } & \multirow{3}{*}{$3 \times 3$} & MEAN & 21.9 & 16.6 & 14.7 & 14 \\
\hline & & & MEDYAN & 21.6 & 14.4 & 11.5 & 10.2 \\
\hline & & & GAUSS & 19.8 & 18.1 & 16.6 & 15.9 \\
\hline & & \multirow{3}{*}{$5 \times 5$} & MEAN & 20.4 & 17.7 & 16 & 15.3 \\
\hline & & & MEDYAN & 20.5 & 16.7 & 14.1 & 12.8 \\
\hline & & & & 19.1 & 17.8 & 16.4 & 15.8 \\
\hline
\end{tabular}




\begin{tabular}{|c|c|c|c|c|c|c|c|}
\hline Görüntü & $\begin{array}{c}\text { Gürültü } \\
\text { Tipi }\end{array}$ & $\begin{array}{l}\text { Maske } \\
\text { Boyutu }\end{array}$ & Filtre Tipi & $\% 1$ & $\% 20$ & $\% 50$ & $\% 80$ \\
\hline & \multirow{6}{*}{ Tuz\&Biber } & \multirow{3}{*}{$3 \times 3$} & MEAN & 29.4 & 20.1 & 15.2 & 12.3 \\
\hline & & & MEDYAN & 33.7 & 28.2 & 15 & 7.8 \\
\hline & & & GAUSS & 26.3 & 22.7 & 17.6 & 14.2 \\
\hline & & \multirow{3}{*}{$5 \times 5$} & MEAN & 27.5 & 21.9 & 16.8 & 13.6 \\
\hline & & & MEDYAN & 30.4 & 28.2 & 22.4 & 10.1 \\
\hline & & & GAUSS & 24.1 & 21.8 & 17.5 & 14.3 \\
\hline \multirow{6}{*}{ LENA } & \multirow{6}{*}{ Gauss } & \multirow{3}{*}{$3 \times 3$} & MEAN & 27.2 & 17.5 & 15.1 & 14.1 \\
\hline & & & MEDYAN & 26.4 & 15.1 & 12 & 10.5 \\
\hline & & & GAUSS & 26.2 & 20.5 & 17.7 & 16.5 \\
\hline & & \multirow{3}{*}{$5 \times 5$} & MEAN & 26.8 & 19.5 & 16.7 & 13.5 \\
\hline & & & MEDYAN & 27.5 & 18.4 & 15.1 & 10 \\
\hline & & & GAUSS & 24.1 & 20.1 & 17.5 & 14.3 \\
\hline \multirow{12}{*}{1} & \multirow{6}{*}{ Tuz\&Biber } & \multirow{3}{*}{$3 \times 3$} & MEAN & 28.4 & 19.6 & 14.5 & 11.5 \\
\hline & & & MEDYAN & 31.8 & 27.4 & 14.7 & 7.6 \\
\hline & & & GAUSS & 25.5 & 21.6 & 16.5 & 13 \\
\hline & & \multirow{3}{*}{$5 \times 5$} & MEAN & 26.9 & 21.2 & 15.9 & 12.5 \\
\hline & & & MEDYAN & 30.1 & 27.8 & 22.2 & 9.8 \\
\hline & & & GAUSS & 23 & 20.6 & 16.3 & 13 \\
\hline & \multirow{6}{*}{ Gauss } & \multirow{3}{*}{$3 \times 3$} & MEAN & 26.6 & 17.1 & 14.5 & 13.5 \\
\hline & & & MEDYAN & 26.1 & 15.3 & 12.1 & 10.7 \\
\hline & & & GAUSS & 25.2 & 19.4 & 16.4 & 15.3 \\
\hline & & \multirow{3}{*}{$5 \times 5$} & MEAN & 26.2 & 18.8 & 15.9 & 14.8 \\
\hline & & & MEDYAN & 27.3 & 18.6 & 15.3 & 13.7 \\
\hline & & & GAUSS & 22.9 & 18.9 & 16.3 & 15.2 \\
\hline
\end{tabular}

PSNR değeri ne kadar yüksek olursa görüntü o kadar kalitelidir. Tablo 1 incelendiğinde; $3 \times 3$ 'lük maske ile $\% 1$ oranında Tuz\&Biber gürültülü görüntü, filtrelerden geçirilmiş ve farkl1 PSNR değerleri elde edilmiştir. Lena görüntüsünün \%1 gürültü hali, Mean filtresinden geçirildiğinde PSNR değeri 29.4 bulunmuş iken Medyan ve Gauss filtresinden geçirildiğinde bu değerler sırasıyla 33.7 ve 26.3 bulunmuştur. 
Medyan filtresinden geçirilmiş görüntüden elde edilen değer, diğer değerlerden büyük olduğu için bu görüntünün orijinal görüntüye en çok benzeyen görüntü olduğu söylenebilir. Tablo 2'de görüntülerin SSIM sonuçları gösterilmiştir.

SSIM değeri, -1 ve 1 arasında değer alır. Bu değer 1'e ne kadar yakın olursa görüntü o kadar kalitelidir. Görüntülerin SSIM ve PSNR ölçütlerine göre karşılaştırılmasında farklılıklar olabilir. Bunun sebebi iki ölçütün de hesaplama şekillerinin farklı olmasıdır.

Tablo 2. Farklı Gürültü Oranları için SSIM Değerleri

\begin{tabular}{|c|c|c|c|c|c|c|c|}
\hline Görüntü & $\begin{array}{c}\text { Gürültü } \\
\text { Tipi }\end{array}$ & $\begin{array}{l}\text { Maske } \\
\text { Boyutu }\end{array}$ & Filtre Tipi & $\% 1$ & $\% 20$ & $\% 50$ & $\% 80$ \\
\hline \multirow{9}{*}{ 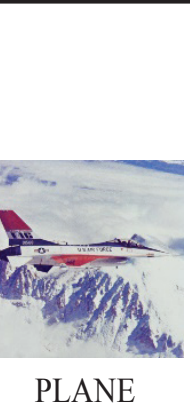 } & \multirow{6}{*}{ Tuz\&Biber } & \multirow{3}{*}{$3 \times 3$} & MEAN & 0.84 & 0.36 & 0.19 & 0.08 \\
\hline & & & MEDYAN & 0.96 & 0.88 & 0.22 & 0.03 \\
\hline & & & GAUSS & 0.82 & 0.66 & 0.48 & 0.32 \\
\hline & & \multirow{3}{*}{$5 \times 5$} & MEAN & 0.84 & 0.49 & 0.29 & 0.15 \\
\hline & & & MEDYAN & 0.92 & 0.90 & 0.73 & 0.08 \\
\hline & & & GAUSS & 0.76 & 0.69 & 0.56 & 0.43 \\
\hline & \multirow{6}{*}{ Gauss } & \multirow{3}{*}{$3 \times 3$} & MEAN & 0.69 & 0.27 & 0.18 & 0.15 \\
\hline & & & MEDYAN & 0.62 & 0.19 & 0.11 & 0.08 \\
\hline & & & GAUSS & 0.80 & 0.59 & 0.49 & 0.44 \\
\hline \multirow{3}{*}{ PLANE } & & \multirow{3}{*}{$5 \times 5$} & MEAN & 0.77 & 0.40 & 0.29 & 0.25 \\
\hline & & & MEDYAN & 0.74 & 0.29 & 0.18 & 0.14 \\
\hline & & & GAUSS & 0.76 & 0.65 & 0.56 & 0.53 \\
\hline \multirow{12}{*}{ BABOON } & \multirow{6}{*}{ Tuz\&Biber } & \multirow{3}{*}{$3 \times 3$} & MEAN & 0.77 & 0.58 & 0.34 & 0.14 \\
\hline & & & MEDYAN & 0.81 & 0.76 & 0.42 & 0.10 \\
\hline & & & GAUSS & 0.60 & 0.54 & 0.40 & 0.21 \\
\hline & & \multirow{3}{*}{$5 \times 5$} & MEAN & 0.65 & 0.55 & 0.37 & 0.17 \\
\hline & & & MEDYAN & 0.67 & 0.65 & 0.58 & 0.18 \\
\hline & & & GAUSS & 0.56 & 0.51 & 0.39 & 0.20 \\
\hline & \multirow{6}{*}{ Gauss } & \multirow{3}{*}{$3 \times 3$} & MEAN & 0.75 & 0.46 & 0.33 & 0.27 \\
\hline & & & MEDYAN & 0.74 & 0.40 & 0.27 & 0.21 \\
\hline & & & GAUSS & 0.60 & 0.50 & 0.40 & 0.35 \\
\hline & & \multirow{3}{*}{$5 \times 5$} & MEAN & 0.65 & 0.47 & 0.37 & 0.31 \\
\hline & & & MEDYAN & 0.64 & 0.46 & 0.35 & 0.30 \\
\hline & & & GAUSS & 0.56 & 0.48 & 0.39 & 0.34 \\
\hline
\end{tabular}




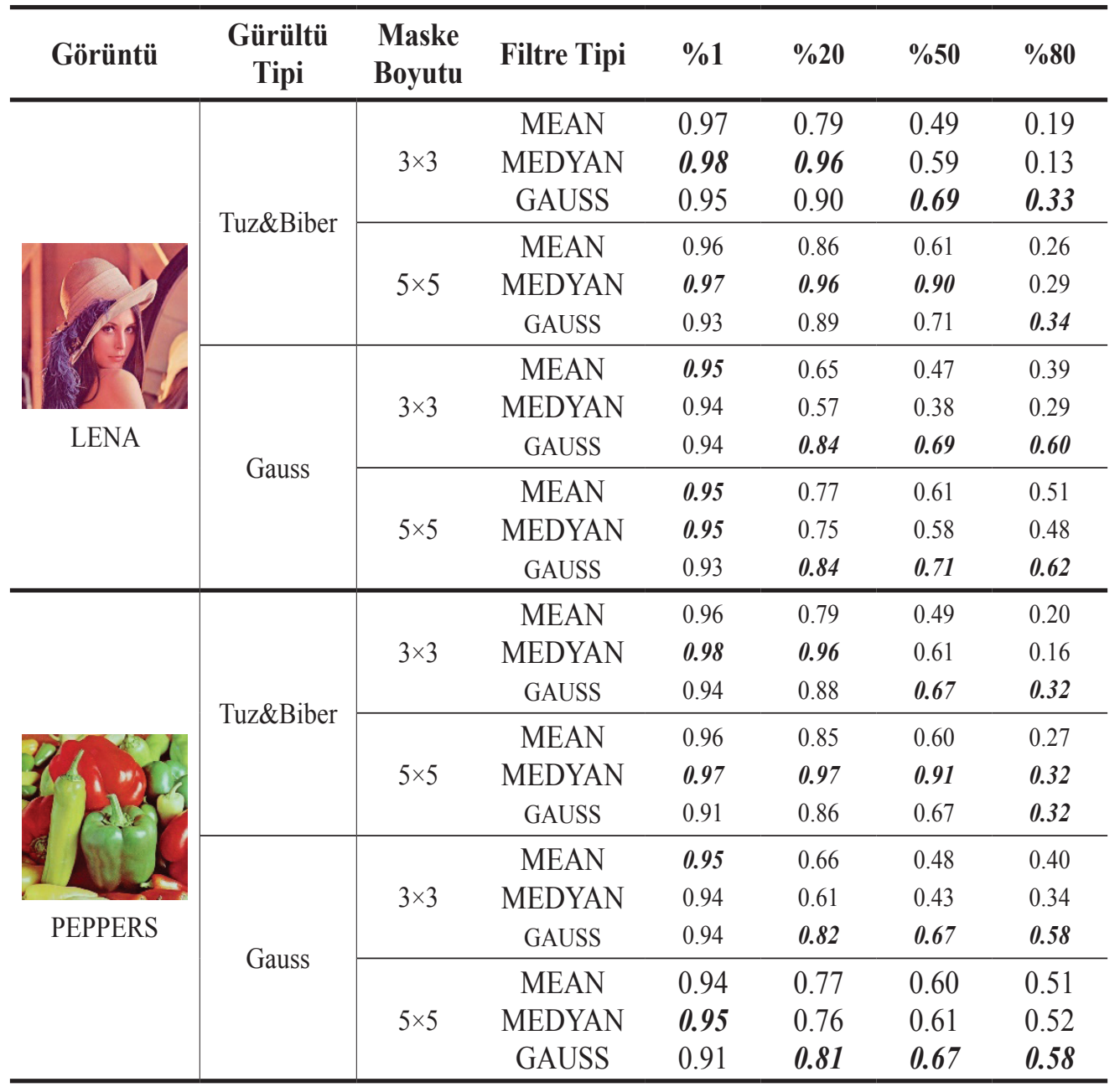

Tablo 2 incelendiğinde $3 \times 3$ 'lük maske ile $\% 1$ oranında Tuz\&Biber gürültülü görüntü, filtrelerden geçirilmiş ve farklı SSIM değerleri elde edilmiştir. Lena görüntüsünün $\% 1$ gürültü hali, Mean filtresinden geçirildiğinde SSIM değeri 0.97 bulunmuş iken Medyan ve Gauss filtresinden geçirildiğinde bu değerler sirasıyla 0.98 ve 0.95 bulunmuştur. Medyan filtresinden geçirilmiş görüntüden elde edilen değer, 1'e en yakın olan değer olduğu için bu görüntünün orijinal görüntüye en çok benzeyen görüntü olduğu söylenebilir. Bu görüntü \%97 oranında orijinal görüntüye benzemektedir. 
Tablo 1 ve Tablo 2'deki değerlerden yola çıkarak, maske boyutu ve gürültü tipleri için ayrı ayrı incelenen SSIM ve PSNR değerleri karşılaştırılıp filtre performans analizi yapılmıştır. Koyu ve italik olarak gösterilen değerler en yüksek değerlerdir. En yüksek değere sahip olan filtreler en başarılı filtrelerdir. Gürültü oranı arttıkça üç filtrenin de performansı azalmıştır.

Tuz\&Biber gürültüsü $3 \times 3$ 'lük maske ile filtrelenirken; gürültü oranının \%1 ile \%20 arasında olduğu durumlarda Medyan filtresi daha başarılı olmuş, gürültü oranının $\% 50$ ve üzeri olduğu durumlarda Gauss filtresi daha başarılı olmuştur.

Tuz\&Biber gürültüsü $5 \times 5$ 'lik maske ile filtrelenirken; gürültü oranının $\% 1$ ile $\% 50$ arasında olduğu durumlarda Medyan filtresi başarılı olmuş, gürültü oranının \%80 ve üzeri olduğu durumlarda Gauss filtresi daha başarılı olmuştur. Maske boyutu arttırıldığında Mean filtresinin, maske boyutunun düşük olduğu durumlara göre daha başarılı olduğu gözlemlenmiştir. Medyan ve Gauss filtrelerinin ise sadece \%20 ve üzeri gürültü oranında daha başarılı olduğu gözlemlenmiştir.

Gauss gürültüsü $3 \times 3$ 'lük maske ile filtrelenirken; gürültü oranının $\% 1$ ile \%20 arasında olduğu durumlarda Mean filtresi daha başarılı olmuş, gürültü oranının \%20 ve üzeri olduğu durumlarda Gauss filtresi daha başarılı olmuştur.

Gauss gürültüsü $5 \times 5$ 'lik maske ile filtrelenirken; PSNR değerlerine göre gürültü oranının $\% 1$ ile $\% 20$ arasında olduğu durumlarda Medyan filtresi, \%20'nin üzerindeki gürültü oranları için Gauss filtresi daha başarılı olmuştur. SSIM değerleri karşılaştırıldığında ise \%1 ile \%20 arasındaki gürültü oranları için Mean veya Medyan filtresi, $\% 20$ ve üzeri gürültü oranları için ise Gauss filtresi başarılı olmuştur. Maske boyutu arttırıldığında Mean ve Medyan filtresinin, maske boyutunun düşük olduğu durumlara göre daha başarılı olduğu gözlemlenmiştir. Gauss filtresinin ise gürültü oranının \%1 ile \%20 arasında olduğu durumlarda performansının azaldığı, diğer durumlarda performansının arttığı gözlemlenmiştir.

Şekil 16'da Lena görüntüsünün \%1, \%20, \%50, \%80 Tuz\&Biber gürültüsünde Mean, Medyan ve Gauss filtreleriyle karşılaştırmalı sonuçları gösterilmiştir. Filtreleme yapılırken 3×3'lük pencere kullanılmıştır. 

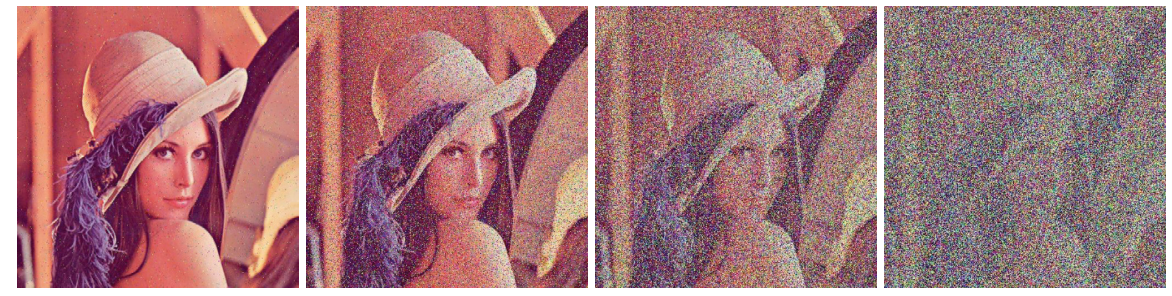

\%1 Gürültülü

\%20 Gürültülü

\%50 Gürültülü

\%80 Gürültülü
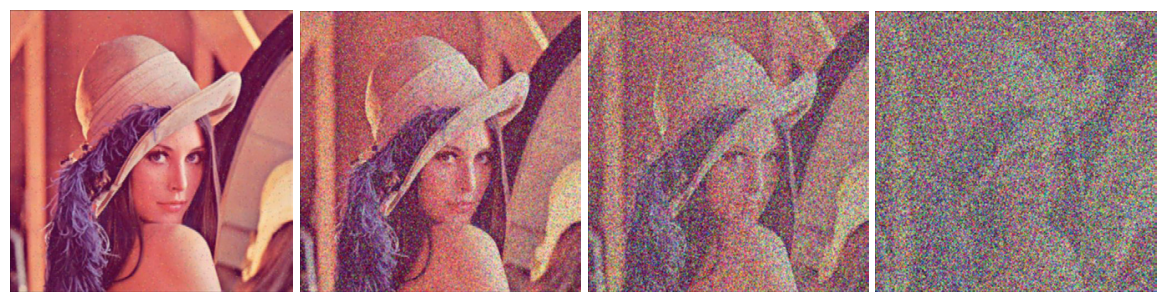

\title{
Mean F-\%1
}

Mean F-\%20

\begin{abstract}
Mean F-\%50
\end{abstract}
Mean F-\%80

Temizlenmiş

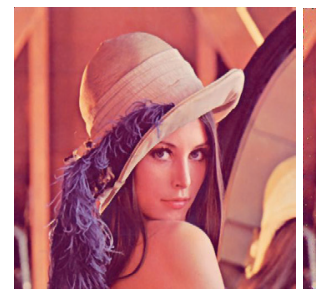

Temizlenmiş

Temizlenmiş

Temizlenmiş

Medyan F-\%1 Temizlenmiş
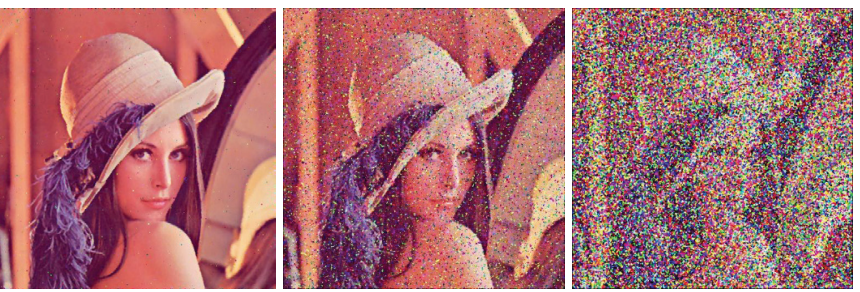

Medyan F-\%20

Medyan F-\%50 Medyan F-\%80 Temizlenmiş Temizlenmiş

Temizlenmiş

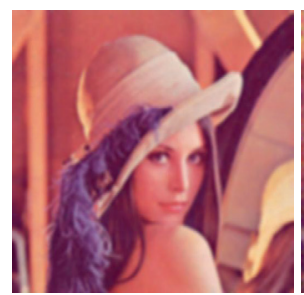

Gauss F-\%1 Temizlenmis

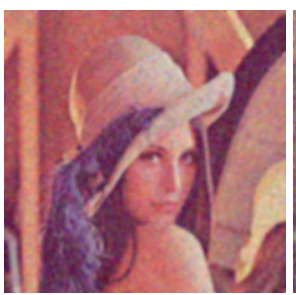

Gauss F-\%20 Temizlenmis

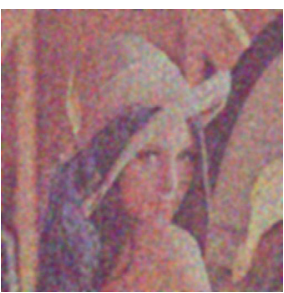

Gauss F-\%50 Temizlenmiș

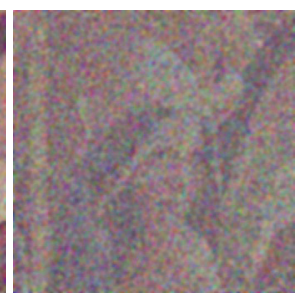

Gauss F- $\% 80$

Temizlenmiş

Şekil 16. Lena Görüntüsünün Farklı Yoğunluktaki Tuz\&Biber Gürültüsü Sonuçları 
Lena görüntüsünde gürültü oranının $\% 1$ ile $\% 20$ arasında olduğu durumlarda Medyan filtresi daha başarılı olurken, gürültü oranının $\% 50$ ve üzeri olduğu durumlarda Gauss filtresi daha başarılı olmuştur.

\section{Sonuç}

Bu çalışmada, görüntü ve videolara gürültü eklenip filtrelenmesi için MATLAB R2019b ortamında bir arayüz geliştirilmiştir. Bu arayüz geliştirilirken MATLAB GUI'den yararlanılmıştır. 4 adet test görüntüsü kullanılmıştır. Görüntü ve videolara Tuz\&Biber ve Gauss gürültüsü eklenmiştir. Gürültüleri temizlemek için Mean, Medyan, Gauss filtreleri kullanılmıştır. Görüntüler filtrelenirken $3 \times 3$ ve $5 \times 5$ boyutlarındaki maskelerden geçirilmiştir. Filtrelenen görüntülerin kalitesinin değerlendirilmesi için görüntü kalite metrikleri de kullanılmıştır. Metrik olarak PSNR ve SSIM yöntemleri kullanılmıştır. Görüntü kalitesini değerlendirerek filtrelerin performans analizinin yapılması amaçlanmıştır. Gürültü oranlarına ve maske boyutlarına göre filtreler farklı performans göstermiştir. Tuz\&Biber gürültüsünün; $\% 1$ ile $\% 20$ arasinda olduğu durumlarda 3×3'lük Medyan filtresinin, $\% 20$ ile $\% 50$ arasında olduğu durumlarda $5 \times 5$ 'lik Medyan filtresinin, $\% 50$ ve üzeri olduğu durumlarda ise $5 \times 5$ 'lik Gauss filtresinin kullanılması önerilir. Gauss gürültüsünün; \%1 ile \%20 arasında olduğu durumlarda 3×3'lük Mean veya $5 \times 5$ 'lik Medyan filtresinin, \%20'nin üzerindeki gürültülerde ise $3 \times 3$ 'lük veya $5 \times 5$ 'lik Gauss filtresinin kullanılması önerilir.

\section{Kaynaklar}

[1] Ulu A., Özen, Y., Öztürk, E., Dizdaroğlu, B., Renkli İmgelerde Çoklu Gürültü Giderme İşlemi İçin İki Aşamalı Bir Yöntem Geliştirilmesi, International Journal of 3D Printing Technologies And Digital Industry, 2(3), (2018), 22-29.

[2] Erkan, U., Gökrem, L., Tuz-Biber Gürültüsünde Tekrarsız Medyan Filtre, Gaziosmanpaşa Bilimsel Araştırma Dergisi, 6(2), (2017), 11-19. 
[3] Güraksın, G. E., Tuz Biber Gürültülerinin Giderilmesi için k-Ortalama Algoritmas1 Tabanlı Filtre Tasarımı, Süleyman Demirel Üniversitesi Fen Bilimleri Enstitüsü Dergisi, 22(2), (2018), 972-978.

[4] Değirmenci, A., Çankaya, İ., Demirci, R., Gradyan Anahtarlamalı Gauss Görüntü Filtresi, Düzce Üniversitesi Bilim ve Teknoloji Dergisi, 6(1), (2018), 196215.

[5] Yurdusev, A. A., Oral, C., Hekim, M., Mamogram İmgeleri Üzerinde Farklı Süzgeçlerin Etkilerinin İncelenmesi, Mehmet Akif Ersoy Üniversitesi Uygulamalı Bilimler Dergisi, 2(1), (2018), 55-68.

[6] Gonzales, R. C., Woods, R. E., Sayısal Görüntü İşleme, Palme Yayıncılık, Ankara, 2002.

[7] Zhu, Y., Huang, C., An Improved Median Filtering Algorithm for Image Noise Reduction, Physics Procedia, 25, (2012), 609-616.

[8] Pham, C. T., Gamard, G., Kopylov, A., Tran, T. T. T., An Algorithm For Image Restoration With Mixed Noise Using Total Variation Regularization, Turkish Journal of Electrical Engineering \& Computer Sciences, 26, (2018), 2831-2845 Doi:10.3906/elk-1803-100.

[9] URL: https://homepages.cae.wisc.edu/ ece533/images/, 08/09/2020.

[10] İnik, Ö., Ülker, E., Derin Öğrenme ve Görüntü Analizinde Kullanılan Derin Öğrenme Modelleri, Gaziosmanpaşa Bilimsel Araştırma Dergisi, 6(3), (2017), $85-104$.

[11] URL: https://www.opencv-srf.com/2018/03/gaussian-blur.html, 15/05/2020.

[12] Kaş, Ü., Tanyıldızı, E., Euler Renk ve Hareket Büyütme Yöntemlerinin Performans Analizi, Afyon Kocatepe Üniversitesi Fen ve Mühendislik Bilimleri Dergisi, 17(2), (2017), 506-515.

[13] İnan, A., MATLAB ve Programlama, Papatya Yayıncılık, 2004.

[14] Ince, I. F., Ince, O. F., Bulut, F., MID Filter: An Orientation-Based Nonlinear Filter For Reducing Multiplicative Noise, Electronics, 8(9), (2019), 936. 
